\title{
Fate of herpes simplex virus in lymphocytes from inflammatory joint effusions. I. Failure of the virus to grow in cultured lymphocytes
}

\author{
D. J. A. APPLEFORD AND A. M. DENMAN
}

From the Division of Immunological Medicine, Clinical Research Centre, Watford Road, Harrow, Middlesex HAl $3 U J$

SUMMARY The ability of lymphocytes isolated from the blood and synovial effusions of patients with rheumatoid arthritis to support the growth of herpex simplex virus (HSV) was studied. Whereas blood lymphocytes supported virus growth, effusion lymphocytes were usually non-permissive. Lymphocytes obtained from the effusions of patients with other forms of inflammatory arthritis or suspected viral arthritis commonly failed to support the growth of HSV, but the virus grew in effusion lymphocytes from patients with noninflammatory joint disease. Several nonspecific factors which might have accounted for this non-permissiveness were excluded.

Although a viral aetiology for rheumatoid arthritis has long been postulated (Norval and Marmion, 1976), a direct search for viruses in the tissues has so far failed to detect a likely agent (Marmion and Mackay, 1978). Nevertheless, the possibility remains that viruses persist in the cells in a form that has not yet been detected.

Lymphoreticular cells are infected during the pathogenesis of many viral infections and are a plausible site of viral persistence. Cells infected with virus can become refractory to superinfection by another virus. It has been shown, for example, that the infection of human fibroblasts with cytomegalovirus induces interference to subsequent infection with a range of heterologous viruses such as Newcastle disease virus (Seto, 1969; Glasgow, 1974). In addition lymphocytes from persons immunised with yellow fever virus become refractory to in vitro infection by the immunising virus (Wheelock and Edelmann, 1969), whereas lymphocytes from nonimmune donors support the growth of this virus.

We have therefore sought evidence for a viral aetiology in the connective tissue diseases by measuring the growth of herpes simplex virus type 1 (HSV) in lymphocytes obtained from patients with such disorders. This virus invariably grows in cultured lymphocytes from normal donors, whereas blood lymphocytes from patients with a variety

Accepted for publication 11 October 1978.

Correspondence to Dr Denman. of connective tissue diseases commonly fail to support its growth (Denman et al., 1976), a finding which might be attributable to interference by defective virus. In this study we have examined the fate of HSV in lymphocytes from inflammatory synovial effusions. We postulated that virus-infected lymphocytes might be localised to the site of persistent inflammation and that these cells would display interference to one or more test viruses.

\section{Materials and methods}

CLINICAL MATERIAL

Blood samples and synovial effusions from knee joints were obtained from patients with inflammatory arthritis, principally rheumatoid arthritis, but also with other disorders. Diagnoses were based on the criteria of the American Rheumatism Association (ARA Committee, 1958 Revision). Patients with acute, self-limited arthritis accompanying febrile illnesses which could not be diagnosed by clinical or laboratory criteria were classified as suffering from 'acute undiagnosed arthritis'. At the time of study these patients were untreated or receiving only nonsteroidal anti-inflammatory drugs. Patients with rheumatoid arthritis of less than or greater than 6 months' duration were regarded as suffering from 'early' or 'late' disease respectively.

Control effusions were obtained from patients with mechanical knee injuries. Normal blood was obtained from healthy laboratory staff. 
IMMUNOLOGICAL METHODS

Isolation of mononuclear cells. After aspiration, joint fluids were mixed with acid citrate dextrose solution to give a final concentration of $0.0018 \mathrm{~g} / \mathrm{ml}$ dextrose and $0.002 \mathrm{~g} / \mathrm{ml}$ citrate and incubated with $75 \mathrm{IU} / \mathrm{ml}$ of hyaluronidase (Fisons) for $30 \mathrm{~min}$. The cells were washed in buffered salt solution (PBSA) before mononuclear cells were isolated. Blood samples were anticoagulated with $20 \mathrm{Iu} / \mathrm{ml}$ of preservativefree heparin. Mononuclear cells from both sources were obtained by density gradient separation on Ficoll/Triosil (Boyum, 1968), washed twice and resuspended in RPMI 1640 medium, supplemented with $12.6 \mathrm{~g} / 1$ bicarbonate, 5mM HEPES, $2 \mathrm{mM}$ L-glutamine, $10 \%$ fetal calf serum (FSC), and 50 $\mathrm{g} / \mathrm{ml}$ gentamicin.

Isolation of granulocytes. Granulocytes were isolated from whole blood by dextran sedimentation, followed by Ficoll/Triosil density sedimentation of the leucocyte-rich supernatant and resuspension of the pelleted granulocytes. Effusion granulocytes were isolated on Ficoll/Triosil gradients without prior dextran treatment.

Mitogen stimulation. Suspensions of mononuclear cells at $10^{6}$ cells $/ \mathrm{ml}$ were stimulated with phytohaemagglutinin (PHA; Wellcome purified grade) at $0.8 \mu \mathrm{g} / 10^{6}$ cells. The stimulation index was assessed by ${ }^{14} \mathrm{C}$-thymidine uptake over an 18 -hour period 48 hours after mitogen stimulation (Janossy and Greaves, 1971).

Autoradiography. Cytocentrifuge smears of lymphocytes labelled with ${ }^{3} \mathrm{H}$-thymidine were exposed to Kodak AR-10 stripping film for 14 days and stained with May-Grünwald-Giemsa. Labelled cells with 10 or more grains per cell were scored as a percentage of the total cell count.

Differential counts. These were performed on cytocentrifuge preparations stained with MayGrünwald-Giemsa.

Cell viability. This was measured by $0.1 \%$ trypan blue exclusion.

\section{VIROLOGICAL METHODS}

Virus stocks. The HFEM strain of herpes simplex virus type 1 (HSV) was propagated in primary chick embryo fibroblasts (Schmidt, 1969). Vesicular stomatitis virus (VSV) (New Jersey strain) was grown in primary chick embryo fibroblasts.

Infection of mononuclear cells. Mononuclear cells at a concentration of $10^{6}$ viable cells $/ \mathrm{ml}$ were infected with HSV at a multiplicity of infection (MOI) of $0 \cdot 1$ virus particles per cell. The MOI for VSV was also $0 \cdot 1$. The cell suspension was transferred to flatbottomed glass vials, $0 \cdot 3 \times 10^{6}$ cells/vial, and triplicate samples were frozen at $-70^{\circ} \mathrm{C}$ on day 0 to day 5 after infection.
Measurement of virus titres. The suspensions of ? mononuclear cells were repeatedly frozen and thawed and virus was titrated by the semimicre plaque assay method (Zisman and Merigan, 1973) using primary chick embryo monolayers for HSV and V3 cells for VSV.

\section{Results}

HSV invariably grew in PHA-stimulated blood lymphocytes from normal donors, and infectively titres in cultures from normal individuals regularly exceeded $3.0 \mathrm{logs} / \mathrm{ml}$ by the third day of culture. $A_{\omega}^{\circ}$ typical growth curve is illustrated in Fig. 1.

In contrast, lymphocytes from the joint effusions of patients with rheumatoid arthritis of more than 6 months' duration were unable to support theo growth of HSV although virus grew to similar? titres in the lymphocytes from blood of most of theo same patients and in lymphocytes from norma donors (Fig. 2 and Table 1). However, blood lymphocytes from 2 out of 11 patients with early rheumatoid

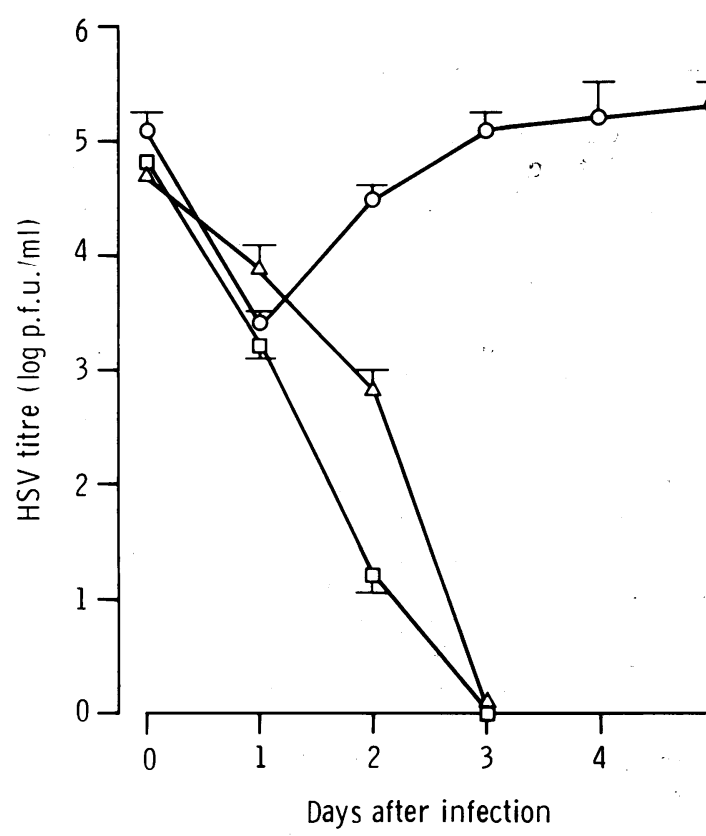

Fig. 1 Normal growth pattern of HSV in human peripheral blood lymphocytes. O-O PHA stimulated, $\triangle-\triangle$ unstimulated, $\square-\square$ heat inactivation. Growth of herpes simplex virus type 1 (HSV) in cultures of lymphocytes from a normal human donor. Unstimulated and PHA stimulated blood lymphocytes were infected at a multiplicity of infection (MOI) of 0.1 and virus infectivity was measured sequentially. Figures are the mean ( \pm I SD) of 3 assays on triplicate cultures. 


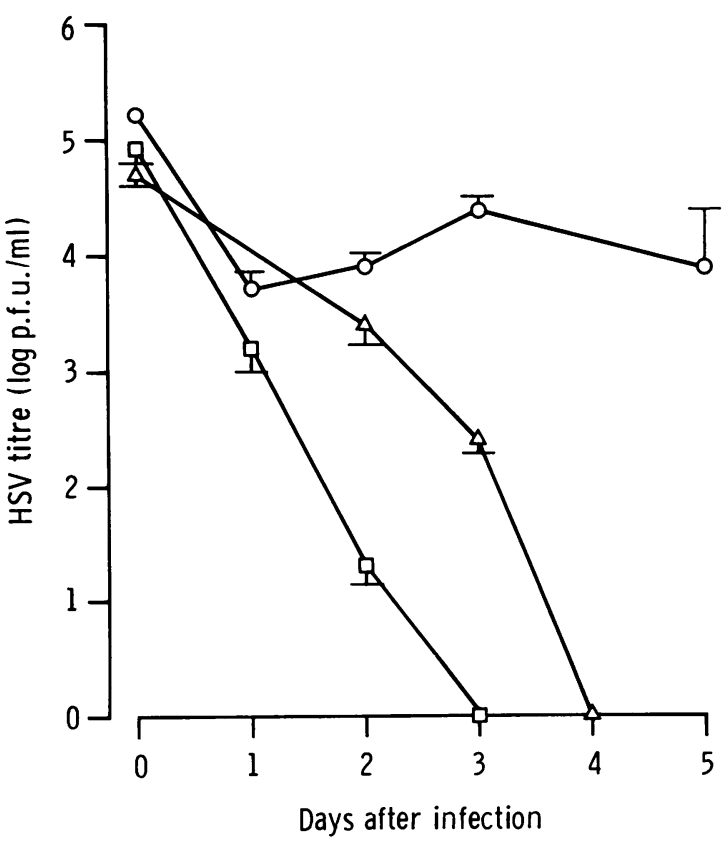

Fig. 2 Non-permissiveness of rheumatoid synovial effusion lymphocytes for $H S V$. O-O blood, $\triangle-\triangle$ effusion, $\square-\square$ heat inactivation. Blood and effusion lymphocytes from the same donor infected with $\mathrm{HSV}$ at an MOI of $0 \cdot 1$. Figures are the mean $( \pm I S D)$ of 3 assays on triplicate cultures.

Table 1 Growth of herpes simplex virus (HSV) in lymphocytes from patients with rheumatoid arthritis $(R A)$

\begin{tabular}{|c|c|c|c|c|c|c|c|}
\hline \multirow[t]{2}{*}{ Disease } & \multicolumn{2}{|c|}{ No. of samples } & \multirow{2}{*}{$\begin{array}{l}\text { Effusions } \\
\text { suitable } 3 \text { for } \\
\text { study }\end{array}$} & \multicolumn{4}{|c|}{$H S V$ infection ${ }^{2}$} \\
\hline & Blood & Effusion & & Blo & & $E f$ & usion \\
\hline $\begin{array}{l}\text { Early RA } \mathbf{A}^{\mathbf{1}} \\
\text { Late RA } \mathbf{R}^{\mathbf{1}}\end{array}$ & $\begin{array}{l}11 \\
23\end{array}$ & $\begin{array}{r}8 \\
87\end{array}$ & $\begin{array}{r}2 \\
18\end{array}$ & $\begin{array}{r}+ \\
9 \\
22\end{array}$ & $\begin{array}{r}- \\
2 \\
1\end{array}$ & $\begin{array}{r}+ \\
1 \\
1\end{array}$ & $\begin{array}{r}- \\
17\end{array}$ \\
\hline
\end{tabular}

1 Early RA and late RA: duration of disease less than or greater than 6 months, respectively. 2 Virus growth scored + if 3 or more logs of virus produced by day 5 of culture, and - if $<1.0 \mathrm{log}$ of virus produced during 5 days of culture. ${ }^{3}$ Those effusions suitable for study were ones containing sufficient lymphocytes for measurement of virus growth.

arthritis failed to support the growth of HSV (Table 1). Synovial effusion lymphocytes from patients with several other forms of inflammatory arthritis were also non-permissive to HSV (Table 2). Only 4 control effusions contained sufficient numbers of lymphocytes to enable virus growth in these cells to be analysed, but of these 4,3 were permissive.

Several factors were examined which might have explained the failure of lymphocytes from rheumatoid synovial effusions to support the growth of HSV.
Table 2 Growth of herpes simplex virus (HSV) in blood and effusion lymphocytes from patients with other forms of inflammatory arthritis

\begin{tabular}{|c|c|c|c|c|c|c|c|}
\hline \multirow[t]{3}{*}{ Disease } & \multicolumn{2}{|c|}{ No. of samiples } & \multirow{2}{*}{$\begin{array}{l}\text { Effusions } \\
\text { suitable }{ }^{2} \\
\text { for study }\end{array}$} & \multicolumn{4}{|c|}{$H S V$ infection 1} \\
\hline & \multirow[t]{2}{*}{ Blood } & \multirow[t]{2}{*}{ Effusions } & & \multicolumn{2}{|c|}{ Blood } & \multicolumn{2}{|c|}{ Effusion } \\
\hline & & & & + & - & + & - \\
\hline $\begin{array}{l}\text { Acute } \\
\text { undiagnosed } \\
\text { arthritis }\end{array}$ & 18 & 5 & 3 & 13 & 5 & 0 & 3 \\
\hline Psoriatic & 2 & 2 & 2 & 1 & 1 & 0 & 2 \\
\hline Reiter's disease & 1 & 1 & 1 & 1 & 0 & 0 & 1 \\
\hline $\begin{array}{l}\text { Seronegative } \\
\text { inflammatory } \\
\text { arthritis }\end{array}$ & 12 & 4 & 1 & 12 & 0 & 0 & 1 \\
\hline $\begin{array}{l}\text { Traumatic } \\
\text { effusions }\end{array}$ & 0 & 16 & 4 & 0 & 0 & 3 & 1 \\
\hline
\end{tabular}

1 Virus growth scored as in Table 1. ${ }^{2}$ Those containing sufficient lymphocytes.

\section{AVAILABILITY OF VIRAL RECEPTORS}

Lymphocyte receptors for HSV might be blocked by hyaluronic acid, since it has been shown that, whereas rubella virus fails to grow in cultured, untreated monolayers of synovial fibroblasts (Grayzel and Beck, 1970), the same cells permit virus growth after hyaluronidase treatment. Similarly lymphocyte surface receptors for herpes viruses are probably identical with immunological cell receptors; for example, Epstein-Barr virus cell receptor is identical to or closely associated with complement receptors on B lymphocytes (Yefenov et al., 1978). These receptors might therefore be blocked by immunoglobulin or complement in the joint fluid.

Accordingly, mononuclear cells isolated from synovial effusions were treated with hyaluronidase $75 \mathrm{Iu} / 10^{6}$ cells for $1 \mathrm{~h}$ at $37^{\circ} \mathrm{C}$ to remove hyaluronic acid or $0.25 \%$ trypsin to remove immunoglobulin. The cells were washed 3 times and incubated at $37^{\circ} \mathrm{C}$ overnight before stimulation with PHA and infection with HSV. The efficiency of trypsin treatment was verified by immunofluorescence staining, which showed that surface immunoglobulin was first deleted and then regenerated (Table 3 ). Infectivity assays showed that, at the standard multiplicity of infection (MOI) of $0 \cdot 1,80-90 \%$ of HSV was absorbed by both blood and joint lymphocytes during the $2 \mathrm{~h}$ incubation period at $37^{\circ} \mathrm{C}$ irrespective of enzyme treatment. However, neither form of enzyme treatment enabled the effusion cells to support virus growth.

\section{LYMPHOCYTE FUNCTION}

Lymphocytes support HSV growth only after appropriate stimulation by mitogens or antigens (Nahmias et al., 1964). Thus the failure of HSV to grow in synovial effusion lymphocytes might merely 
Table 3 Effect of trypsin treatment on the growth of HSV in lymphocytes from normal blood or rheumatoid synovial effusions

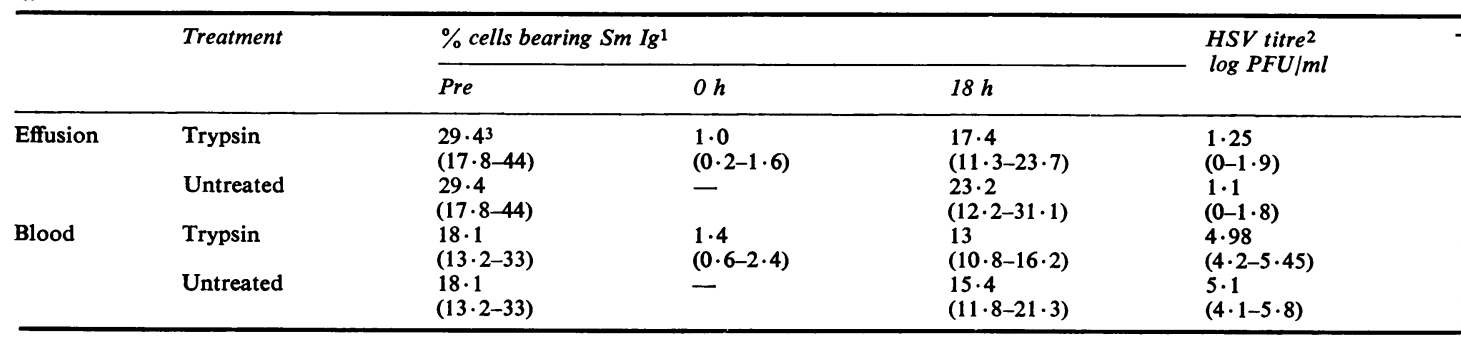

PFU = plaque forming units. 1 Time after trypsin treatment. 2 Maximum HSV titre after 3 or more days of culture (log PFU/ml).

3 Mean (and range) of 4 experiments.

Mononuclear cells were incubated for 1 hour at $37^{\circ} \mathrm{C}$ with $0.25 \%$ trypsin, washed, and incubated for 18 hours prior to PHA stimulation and HSV infection. HSV growth was measured daily for 5 days

reflect the defective response of these cells to PHA, resulting either from the nature of the lymphocytes attracted to the inflammatory site or frorn the inhibitory effects of the effusion fluid. Indeed, the response of rheumatoid synovial effusion lymphocytes is allegedly poor in comparison to that of blood lymphocytes. (Sheldon et al., 1974; Abrahamsen et al., 1978). Accordingly a series of experiments were carried out to exclude these possibilities.

The response of lymphocytes isolated from normal blood and from rheumatoid synovial effusions to PHA was compared with respect both to 'blast' transformation and the ability of the stimulated cells to support virus growth. 'Blast' transformation was assessed by radiochemical and autoradiographical techniques. Judged by autoradiography PHA induced an increase in the percentage of lymphoblasts in cultures of synovial effusion lymphocytes, although this increase was smaller than that observed on PHA stimulation of blood lymphocytes (Table 4). No correlation was found between ${ }^{14} \mathrm{C}$-thymidine incorporation and virus growth in blood or effusion cell cultures, and some cultures of effusion lymphocytes which gave a brisk proliferative response were nevertheless resistant to viral infection (Fig. 3).

In order to exclude the inhibitory effects of the synovial fluid on lymphocyte function, and hence on virus growth, blood mononuclear cells from normal controls were incubated in rheumatoid synovial effusion fluid from which cells and large debris had been removed by centrifugation at $400 \mathrm{~g}$ for $10 \mathrm{~min}$. The fluid was used at a final concentration of $20 \%$ in RPMI growth media. In different experiments the lymphocytes were incubated with effusion fluid during the 18-hour period of PHA stimulation or for the whole period of PHA stimulation and subsequent virus infection assay. Although judged by ${ }^{14} \mathrm{C}$-thymidine uptake, the degree of stimulation produced by PHA was considerably

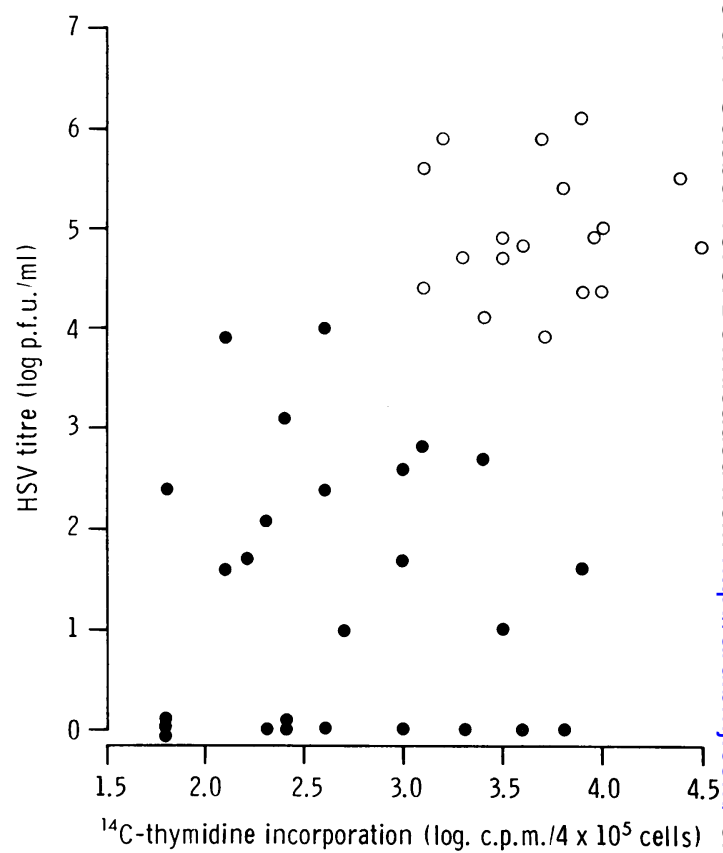

Fig. 3 Relation between HSV growth after infection and mitogen stimulation. effusion lymphocytes O normal blood lymphocytes. Virus titres are maximal titres after 3 or more days of culture. The rank correlation (Kendall's tau) for the effusion data was $0.017(P>0.5)$ and for the blood data was 0.068 $(P>0.5)$. There was therefore no significant correlation between PHA stimulation and virus growth within either sample group.

reduced, exposure to this inflammatory exudate did not inhibit virus growth (Table 5).

The mononuclear cells separated from synovial产 effusions by Ficoll-Triosil sedimentation containedo a higher percentage of granulocytes than preparations 
Table 4 Lymphoblast transformation of lymphocytes from the blood and effusions of patients with rheumatoid arthritis

\begin{tabular}{|c|c|c|c|c|c|c|}
\hline \multirow{2}{*}{$\begin{array}{l}\text { Source of } \\
\text { lymphocytes }\end{array}$} & \multirow[t]{2}{*}{ No. studied } & \multicolumn{2}{|c|}{${ }^{14}$ C-thymidine uptake ${ }^{1}$} & \multirow[t]{2}{*}{ No. studied } & \multicolumn{2}{|l|}{$\%$ Blasts $^{2}$} \\
\hline & & PHA stimulated & Unstimulated & & PHA stimulated & Unstimulated \\
\hline Normal blood & 20 & $\begin{array}{l}8912 \\
(1259-31622)\end{array}$ & $\begin{array}{l}128 \\
(62-357)\end{array}$ & 3 & $\begin{array}{l}44 \\
(34-52)\end{array}$ & $\begin{array}{l}4 \\
(1-7)\end{array}$ \\
\hline RA blood & 20 & $\begin{array}{l}3283 \cdot 6 \\
(1120-5594)\end{array}$ & $\begin{array}{l}134 \\
(35-971)\end{array}$ & 4 & $\begin{array}{l}26 \cdot 7 \\
(14-37)\end{array}$ & $\begin{array}{l}3 \cdot 7 \\
(2-7)\end{array}$ \\
\hline RA effusion & 20 & $\begin{array}{l}1726 \cdot 1 \\
(75-8471)\end{array}$ & $\begin{array}{l}96 \cdot 8 \\
(32-320)\end{array}$ & 4 & $\begin{array}{l}17 \cdot 5 \\
(14 \cdot 0-22 \cdot 0)\end{array}$ & $\begin{array}{l}5 \cdot 7 \\
(3-9)\end{array}$ \\
\hline
\end{tabular}

1 After 72 hours of culture. 2 Judged by autoradiography after the same period of culture.

Table 5 Effect of synovial fluid on the growth of HSV in normal blood lymphocytes

\begin{tabular}{llll}
\hline Treatment & $\begin{array}{l}14 \text { C-thymidine uptake (c.p.m./ } \\
\left.4 \times 10^{5} \text { cells }\right)\end{array}$ & $\begin{array}{l}\text { HSV growth } \\
(\text { log PFU } / m l)\end{array}$ \\
\cline { 2 - 3 } & PHA stimulated & Unstimulated & \\
\hline $20 \%$ Synovial fluid & 30212 & 717 & $4 \cdot 2$ \\
& $(2380-3622)$ & $(658-771)$ & $(3 \cdot 4-5 \cdot 2)$ \\
Untreated & $8175 \cdot 8$ & 317 & $4 \cdot 4$ \\
& $(4537-14979)$ & $(175-486)$ & $(4 \cdot 2-4 \cdot 8)$ \\
\hline
\end{tabular}

PFU = plaque forming units. 1 HSV titre scored as in Table 3. 2 Figures are mean (and range) of 3 experiments.

Normal blood lymphocytes were cultured in medium containing $20 \%$ rheumatoid synovial fluid during PHA stimulation and subsequent virus infection.

of blood mononuclear cells prepared by the same technique. Whereas the effusion preparations contained 46-99\% mononuclear cells, the blood mononuclear cell preparations invariably contained $92 \%$ or more of this cell type. Granulocytes could have blocked virus growth not only by diluting the number of potentially permissive cells but also by interfering with virus growth in the susceptible subpopulation of lymphocytes.

Accordingly, blood mononuclear cells from a patient with rheumatoid arthritis and from a normal donor were diluted in varying proportions with granulocytes obtained either from normal blood or from the effusion of a patient with rheumatoid arthritis. Cell muxtures in which the percentage of blood lymphocytes exceeded $30 \%$ invariably supported virus growth (Fig. 4), a figure which was exceeded in all starting preparations of effusion lymphocytes. Moreover, the same results were obtained whether the granulocytes were derived from the blood or from the synovial effusions. Mixtures of viable blood lymphocytes and autologous actinomycin-D-treated lymphocytes which could not support virus growth were also permissive provided the percentage of viable cells exceeded this figure. Thus granulocyte contamination is unlikely to have accounted for the failure of synovial effusion lymphocytes to support the growth of HSV.

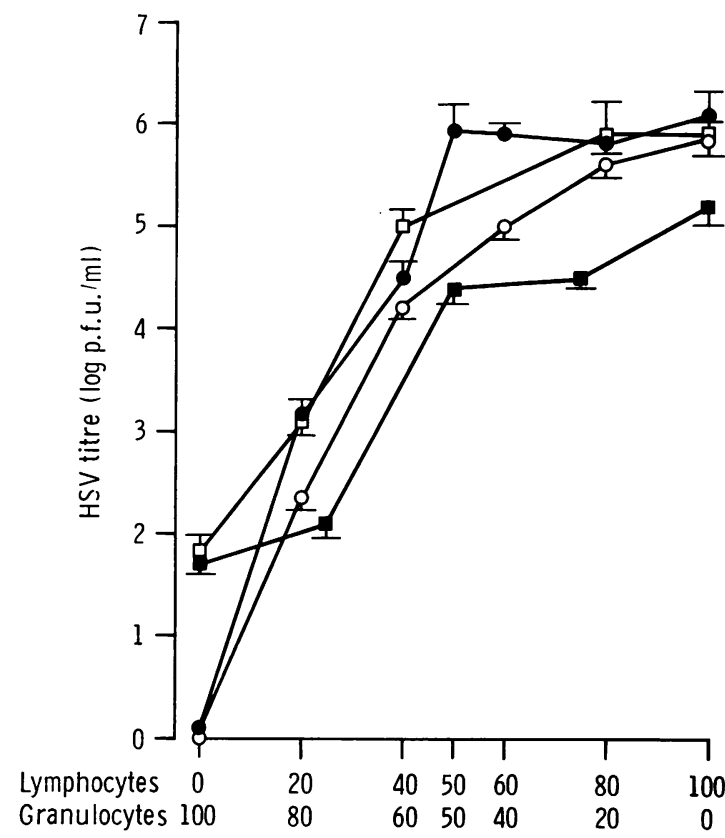

Fig. 4 Effect of granulocytes on the growth of $\mathrm{HSV}$ in cultures of peripheral blood lymphocytes $(P B L) \square-\square$ normal PBL mixed with autologous blood granulocytes, O-O normal PBL mixed with effusion granulocytes, - $R A$ PBL mixed with effusion granulocytes, normal $P B L$ mixed with autologous actinomycin- $D$ treated PBL. Vial growth is the maximum after 3 to 5 days of culture

\section{GROWTH OF VESICULAR STOMATITIS VIRUS IN RHEUMATOID SYNOVIAL EFFUSION LYMPHOCYTES}

The ability of rheumatoid synovial effusion lymphocytes to support the growth of viruses other than HSV was tested with vesicular stomatitis virus (VSV), since this virus invariably grows in PHAstimulated peripheral blood lymphocytes from normal donors and has been reported to grow in rheumatoid synovial effusion lymphocytes (Zisman 
Table 6 Growth of vesicular stomatitis virus in blood and effusion lymphocytes from patients with rheumatoid arthritis

\begin{tabular}{lll}
\hline $\begin{array}{l}\text { Source of } \\
\text { lymphocytes }\end{array}$ & $\begin{array}{l}H S V \text { titre }(\log \\
P F U / m l)^{1}\end{array}$ & $\begin{array}{l}\text { VSV titre }(\log \\
P F U / m l)^{1}\end{array}$ \\
\hline Normal blood & $5 \cdot 12$ & $5 \cdot 4$ \\
& $(4 \cdot 9-5 \cdot 4)$ & $(5 \cdot 3-5 \cdot 6)$ \\
RA effusion & $0 \cdot 9$ & $3 \cdot 5$ \\
& $(0-1 \cdot 4)$ & $(3 \cdot 2-3 \cdot 9)$ \\
\hline
\end{tabular}

PFU = plaque forming units. $1 \mathrm{HSV}$ and VSV titre estimated as in Table 3. 2 Mean (and range) of 3 experiments.

Lymphocytes from normal blood and RA effusions were stimulated with PHA and the cultures divided after 18 hours for infection with either HSV or VSV.

et al., 1973). VSV grew in lymphocytes from the latter source, although the titres were lower than those obtained in cultures of peripheral blood lymphocytes (Table 6).

\section{Discussion}

In this study we sought indirect evidence for a viral aetiology of rheumatoid arthritis. We postulated that lymphocytes that are persistently infected with virus, or that are mounting an immune response to a virus infection of other body tissues, will fail to support the growth of viruses for which these lymphocytes are normally permissive. Studies on patients with systemic connective tissue diseases showed that blood lymphocytes failed to support the growth of HSV, a virus which replicates in PHA-stimulated lymphocytes from normal donors (Denman et al., 1976), indicating that this agent is a useful probe for detecting possible interference. Blood lymphocytes from patients with rheumatoid arthritis also support the growth of HSV in normal fashion, but we hypothesised that in this disease it would be necessary to examine lymphocytes from the affected site.

The results show that lymphocytes from rheumatoid synovial effusions were usually non-permissive for HSV. Lymphocytes from the effusions of patients with other forms of inflammatory arthritis also commonly failed to support the growth of this virus. However, synovial effusion lymphocytes from patients with noninflammatory joint disease supported the growth of HSV. Although these results were consistent with an interference phenomenon, several nonspecific factors were considered which might have produced the same results.

Virus entry into lymphocytes might have been blocked by factors in the inflammatory joint fluid, including components of the immune reaction such as immune complexes reactive with Fc or complement receptors. In addition hyaluronic acid is known to block the entry of rubella viruṣ? into susceptible cells (Grayzel et al., 1970). However enzyme treatment, which removed these components? did not enable synovial effusion lymphocytes to support HSV growth. Furthermore, irrespective of enzyme treatment virus absorbed as efficiently to these lymphocytes as it did to blood lymphocytes?

It was also possible that synovial effusion lymphos cytes responded inadequately to PHA, either because the selected subpopulations of lymphocytes that migrate to the affected joint are impoverished in this respect or because residence in the effusion produces a similar result. The proliferative response. to PHA, which is necessary for HSV growt 150 (Nahmias et al., 1964), was indeed less marked iợ cultures of effusion lymphocytes than in bloo $\$$ lymphocytes. However, there was no correlation between viral growth and the degree of stimulation? judged by ${ }^{14} \mathrm{C}$-thymidine incorporation, and some cultures which were markedly deficient in this respect supported viral growth efficiently.

The lymphokines in joint fluids (Statsny et al. 1975) might inhibit the growth of HSV in lympho $\overrightarrow{0}$ cytes. In addition prostaglandins, produced by macrophages, may reduce PHA stimulation in inflammatory exudate lymphocytes (Markensore et al., 1977). Since virus growth was not inhibite of in normal blood lymphocytes exposed to join fluid, these factors did not account for the results Furthermore, treating effusion lymphocytes with indomethacin, which blocks the effect of prosta glandins on PHA responsiveness of lymphocytes (Markenson et al., 1977), did not alter the non permissiveness of effusion lymphocytes for $\mathrm{HSV}$. (unpublished observations).

Granulocytes might conceivably have interfere of with virus growth in synovial effusion lymphocytes but this possibility was excluded by the results of experiments in which effusion granulocytes, mixedB with normal lymphocytes at concentrations regularlyo exceeded in all our experiments, failed to block HSV growth. These results indicate that the inability of lymphocytes from patients with inflammatory arthritis to support the growth of HSV is an intrinsie property of these lymphocytes and is not induced by the inflammatory process itself.

Since HSV was used routinely in these experiments we wanted to know whether the failure to replicat was specific for this virus or applied to other viruses $\frac{-}{\mathbb{D}}$ VSV was therefore used as a test of specificity, and? in agreement with a previous report (Zisman et al.;0 1973), this virus was found to grow in effusion lymphocytes. This finding indicates that there is nof fundamental defect in the metabolism of these cellsD which precludes the growth of all viruses. In addition? it indicates that the failure of HSV to grow in synoviaf 
effusion lymphocytes shows some degree of selectivity, although too few viruses have been studied to allow a more definite statement.

The biological significance of these findings is considered in an accompanying paper.

The authors would like to thank Drs B. M. Ansell, J. M. Gumpel, and D. S. Smith for their assistance in obtaining clinical material.

\section{References}

Abrahamsen, T. G., Froland, S. S., and Natvig, J. B. (1978). In vitro mitogen stimulation of synovial effusion lymphocytes from rheumatoid arthritis and juvenile arthritis patients. Dissociation between the response to antigens and polyclonal mitogens. Scandinavian Journal of Immuno$\log y, 7,81-90$.

Boyum, A. (1968). Separation of leukocytes from blood. Scandinavian Journal of Clinical and Laboratory Investigation, 21, Suppl. 97, 1.

Denman, A. M., Pelton, B. K., Appleford, D. J. A., and Kinsley, M. (1976). Virus infections of lymphoreticular cells and auto-immune diseases. Transplantation Reviews, 31, 79-115.

Glasgow, L. A. (1974). Cytomegalovirus interference in vitro. Infection and Immunity, 9, 702-707.

Grayzel, A. I., and Beck, C. (1970). Rubella infection of synovial cells and the resistance of cells derived from patients with rheumatoid arthritis. Journal of Experimental Medicine, 131, 367-373.

Janossy, G., and Greaves, M. F. (1971). Lymphocyte activation. I. Response of T and B lymphocytes to phytomitogens. Clinical and Experimental Immunology, 9, 483-498.

Markenson, J. A., Morgan, J. W., Joachim, C. L., and Lockshin, M. D. (1977). Response of whole and T lymphocyte populations to mitogen in patients with SLE rheumatoid arthritis, and normal volunteers. Arthritis and Rheumatism, 20, 127-128.

Marmion, B. P., and Mackay, J. M. K. (1978). Rheumatoid arthritis and the virus hypothesis. In Experimental Models of Chronic Inflammatory Diseases, pp. 188-211. Edited by L. E. Glynn, and H. D. Schlumberger, Spinger: Berlin.

Nahmias, A., Kibrick, S., and Rosan, R. C. (1964). Viral leukocyte inter-relationships. I. Multiplication of a DNA virus-herpes simplex virus in human leukocyte cultures. Journal of Immunology, 93, 69.

Norval, M., and Marmion, B. P. (1976). Attempts to identify virsuses in rheumatoid synovial cells. Annals of the Rheumatic Diseases, 35, 103-106.

Seto, D. S. Y. (1969). Interaction between cytomegalovirus and Newcastle disease virus as mediated by intrinsic interference. Journal of Virology, 4, 12-14.

Schmidt, N. J. (1969). Diagnostic Procedures for Viral and Rickettsial Infection, 4th edn., Ch. 3. Edited by E. H. Lennette and N. J. Schmidt. American Public Health Association: New York.

Sheldon, P. J., Papamichael, M., and Holborrow, E. J. (1974). Studies on synovial fluid lymphocytes in rheumatoid arthritis. Annals of the Rheumatic Diseases, 33, 509-514.

Statsny, P., Rosenthal, M., Andreis, M., Cooke, D., Ziff, M. (1975). Lymphokines in rheumatoid synovitis. Annals of the New York Academy of Sciences, 256, 117-130.

Wheelock, E. F., and Edelman, R. (1969). Specific role of each leukocyte type in viral infection. III. 17D-yellow fever virus replication and interferon production in homogenous leukocyte cultures with P.H.A. Journal of Immunology, 103, 429-436.

Yefenov, E., Akacs, T. B., Einhorn, L., Ernberg, I., and Klein, G. (1978). Epstein-Barr virus receptors, complement receptors and E.B.V. infectibility of different lymphocyte fractions of human peripheral blood. I. Complement receptor distribution and complement binding by separated lymphocyte subpopulations. Cellular Immunology, 35, 34-42.

Zisman, B., Loewi, G., and Dorling, J. (1973). Proliferation of vesicular stomatitis virus (VSV) in leukocytes from rheumatoid patients. Annals of the Rheumatic Diseases, 32, 219-222.

Zisman, B., and Merigan, T. C. (1973). A useful quantitative semi-micro method for viral plaque assay. Proceedings of the Society for Experimental and Biological Medicine, 142, 1174. 